\title{
Ars aequi et boni, legal argumentation and the correct legal solution
}

\author{
Von
}

\section{Philip Thomas}

\begin{abstract}
Zusammenfassung: Der Beitrag widmet sich den Anfängen rechtlicher Argumentation, die auf das römische Recht und, genauer, auf die republikanische Rechtswissenschaft zurückgehen. Ausgangspunkt ist die These von Stroux, dass das alte formalistische Paradigma in jener Zeit durch ein neueres verdrängt worden sei, in dem die Fairness eine prominente Rolle spielte, und dessen Begründung und Methode aus der griechischen Redekunst geschöpft worden sei. Neben Stroux steht Viehwegs Theorie einer topischen Jurisprudenz. Diese von Nichtjuristen formulierten Thesen werden konfrontiert mit der communis opinio doctorum, die von Schulz, Kaser und Wieacker repräsentiert wird. Es soll gezeigt werden, dass neuere Erkenntnisse in der Rechtstheorie eine nuanciertere Bewertung der Arbeiten von Stroux und Viehweg ermöglichen, die die Grundlagen der westlichen Rechtswissenschaft keineswegs in Frage stellen*).
\end{abstract}

\section{Introduction:}

In his critique on legal education ${ }^{1}$ ) Duncan Kennedy asserts that law teachers indoctrinate their students that there exists an analytical process, so-called thinking like a lawyer, which is taught to them so they can find the correct legal solution. Hans Ankum finds the relevance of Roman law in legal education in the fact that it teaches the students to think ${ }^{2}$ ), which links legal

*) This work is based on the research supported wholly by the National Research Foundation of South Africa (Grant specific unique reference number UID 85777); the Grantholder acknowledges that opinions, findings and conclusions or recommendations expressed in any publication generated by the NRF supported research are that of the author, and that the NRF accepts no liability whatsoever in this regard.

1) D. Kennedy, Legal education as training for hierarchy, in: D. Kairys (ed.), The Politics of Law, A Progressive Critique, New York 1982, 38-58. Kennedy also mentions that the students are taught a list of pro and contra arguments used by lawyers to argue whether a certain rule is applicable or not, but the punch line actually is that the teachers decide which arguments are valid in certain cases and vice versa.

$\left.{ }^{2}\right)$ C.H. Van Rhee/L.C. Winkel, Een Romeinsrechtelijke coryfee, Rechtshistorici uit de Lage Landen (11): Interview met Hans Ankum, in: Pro Memorie: Bijdra- 
argumentation to Roman law. Both Ankum and Kennedy are reticent about this thought process, just as their Roman predecessors ${ }^{3}$ ). It is generally acknowledged that the Roman jurists were primarily practice-orientated ${ }^{4}$ ) and the only theoretical or philosophical works are by the "renaissance man" of Rome, Cicero.

Modern literature on legal argumentation is copious, but this paper does not enter into this specialised debate, neither into the discussions about Greek philosophy ${ }^{5}$ ), science ${ }^{6}$ ), philosophy of science or the Roman or modern understanding, absorption and modification of the above ${ }^{7}$ ). The question whether law is an art, a science, a technique or a philosophy ${ }^{8}$ ) and the variations of the status theory will be left to your own imagination ${ }^{9}$ ).

gen tot de rechtsgeschiedenis der Nederlanden 12 (2010), 146-167 at 164: "Als je mij vraagt wat de relevantie is van het Romeinse recht, dan zou ik zeggen: leren denken."

$\left.{ }^{3}\right) \mathrm{N}$. Benke, In sola prudentium interpretatione, $\mathrm{Zu}$ Methodik und Methodologie römischer Juristen, in: B. Feldner/N. Forgó (eds.), Norm und Entscheidung, Prolegomena zu einer Theorie des Falls, Wien 2000, 1-85, at 75-82 explains this lack of information on methodology as a policy to control and retain a monopoly.

$\left.{ }^{4}\right)$ P. Stein, Interpretation and legal reasoning in Roman law, in: Chicago-Kent Law Review 70 (1994/5), 1539-1556 at 1539.

$\left.{ }^{5}\right)$ A recurring argument in the discourse on Roman methodology is that the adherents of diverging opinions have misunderstood Aristotle. Cf. W. Waldstein, Topik und Intuition in der römischen Rechtswissenschaft, in: F. Horak/W. Waldstein (eds.), Festgabe für Arnold Herdlitczka, 1972, 237-263 at 245.

$\left.{ }^{6}\right)$ For a concise introduction in theory of science see F. Horak, Rationes decidendi, Entscheidungbegründungen bei den älteren römischen Juristen bis Labeo, 1969, 9-22. Cf. Th. Viehweg, Topik und Jurisprudenz, Ein Beitrag zur rechtswissenschaftlichen Grundlagenforschung, 1953; Benke (n. 3); and K. Riesenhuber, English common law versus German Systemdenken? Internal versus external approaches, in: Utrecht Law Review 1 (2011) 117-130 for alternative ideas.

$\left.{ }^{7}\right)$ Quint. inst. 3,11,21: Verum haec adfectata subtilitas circa nomina rerum ambitiose laborat.

$\left.{ }^{8}\right)$ Horak, Rationes (n. 6) 23ff., adresses the problem and refers to literature. At 34f. he mentions that in spite of all criticism Kelsen's Reine Rechtslehre remains the only scientific legal theory; also 25 for the attitude of jurists. Cf. also J. Heng st 1, Gab es Rechtswissenschaft in der außerrömischen Antike?, in: R. van den Bergh/G. van Niekerk (eds.), Libellus ad Thomasium, Essays in Roman law, Roman-Dutch law and Legal History in honour of Philip J. Thomas, Pretoria 2010, 164-183; B enke (n. 3) passim; D. van der Merwe, Regsmetodologie; 'n Terreinverkenning in historiese perspektief, in: Tydskrif vir die Suid Afrikaanse Reg [TSAR] 1 (1987) 129-152 at $147 \mathrm{f}$.

9) Cf. Quint. inst. 3,11,24: Neque est vere quis quammodo non stultus ..., quin sciat, et quid litem faciat, (quod ab illis causa vel continens dicitur) et quae sit inter litigants quaestio, et de quo iudicario porteat, quae omnia idem sunt: Since anybody but a fool 
The topic of this essay is the origin of legal argumentation in Roman law and a warming-up of the hypothesis proposed by Stroux and Viehweg that the methodology of legal argument in Roman law derived from rhetoric; the response of prominent Romanists will be addressed; which necessitates a short review of the position of the Roman jurist, while the didactic myth of the correct legal solution is given some attention.

2. Alternative narratives of the development of Roman law, legal argumentation and legal science:

It remains a baffling question how the legal system in which a person who instituted an action because his vines had been cut, would lose his case because the text of the Twelve Tables stipulated trees ${ }^{10}$ ), developed into what Celsus described as the ars boni et aequi ${ }^{11}$ ).

This question was addressed in 1926 by Johannes Stroux ${ }^{12}$ ), professor of classical philology at the University of Munich. He found the answer in the status theory in Greek rhetoric ${ }^{13}$ ) and argued that when the old formalistic paradigm in Roman law was challenged by new ideas ${ }^{14}$ ), rhetoric offered a fully developed theory and terminology. This happened because rhetoric had become the one and only study for upper-class Romans ${ }^{15}$ ), so every politician, jurist, advocate or general, not only in preparing a speech, but in addressing any problem, would fall back on the only available theory providing him with arguments pro and contra. Stroux concentrated on issuespotting ${ }^{16}$ ) and showed that within rhetoric the theory of interpretation of statutes $^{17}$ ) provided a variety of different angles of approach, viewpoints and

knows that the main issue (or what they call it) and the legal question and the point on which the judge must decide are all identical.

$\left.{ }^{10}\right)$ Gaius inst. 4,11; also 4,30.

$\left.{ }^{11}\right)$ D. 1,1,1 pr. Waldstein (n. 5) at 260 n. 114 mentions that Beseler considered the whole text an interpolation, rhetoric, full of ethics, but more in the style of the fathers of the church than of classical jurists.

${ }^{12}$ ) J. Stroux, Summum Ius Summa Iniuria, Ein Kapitel aus der Geschichte der interpretatio iuris, in: Festschrift Paul Speiser-Sarasin (1926); cited from reprint in J. Stroux, Römische Rechtswissenschaft und Rhetorik, Potsdam 1949, 9-66.

13) Stroux 1949 (n. 12) at 23f. takes one step back and speculates how from the raw material of a case the legal question is formulated.

14) Stroux 1949 (n. 12) 10f.

15) At 25 .

16) Kennedy (n. 1) at 42: "issue spotting," which means identifying the ways in which the rules are ambiguous, in conflict, or have a gap when applied to particular fact situations.

${ }^{17}$ ) Stroux (n. 12) at $27 \mathrm{ff}$. summarises the rhetorical theory of interpretation: 
arguments, topoi or topica ${ }^{18}$ ). Since both sides of the question are to be argued, a dialectic process of argument and counterargument prepared for legal argument. Stroux referred to the cause célèbre of the causa Curiana and Cicero's Pro Caecina to prove his point ${ }^{19}$ ). The emphasis of his essay fell on the introduction of the rhetorical status ex voluntate contra scriptum into legal interpretation and the resulting development of equity in Roman law ${ }^{20}$ ); however, the message of Stroux's proposition is that the old paradigm in Roman law was confronted by modern ideas on equity, and that the theory and methodology of the new paradigm derived from Greek rhetoric. In this

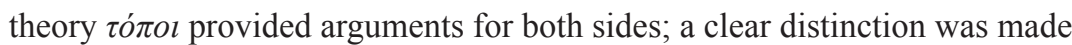
between the individual case and the abstract question ${ }^{21}$ ), and the status theory offered a method to analyse legal problems in order to prepare argumentation $^{22}$ ). The essay of Stroux was received with enthusiasm by Riccobono ${ }^{23}$ ), who considered it essential for the understanding of the development of Roman law and a death-blow to the ruling interpolationist paradigm ${ }^{24}$ ). On the other hand Beseler ${ }^{25}$ ) wanted to burn the book ${ }^{26}$ ).

The ruling paradigm was represented by Schulz, who in his History of Ro-

Scriptum et voluntas at 33-38; antinomia, leges contrariae at 38-39; amphibolia, ambiguitas at 31f.; syllogismus, ratiocinatio, collectio at 39-40; Stroux mentions that variations were also supported.

${ }^{18}$ ) Stroux (n. 12) at 31-41. For the divergent meanings see van der Merwe (n. 8).

$\left.{ }^{19}\right)$ At 42-48. See also F. Wi e a cker, The causa Curiana and contemporary Roman jurisprudence, in: The Irish Jurist 2 (1967) 151-164; O. Tellegen-Couperus, Cicero and Ulpian, two paragons of legal practice, RIDA 55 (2008) 485-497.

${ }^{20}$ ) Stroux (n. 12) at 57 where he and Cicero point out the pernicious habit which developed where advocates relied on so-called equity to persuade judges to ignore the law.

${ }^{21)}$ Stroux (n. 12) 61; Cic. inv. 1,9; de orat. 2,133; 2,141.

${ }^{22}$ ) F. Horak, Die rhetorische Statuslehre und der moderne Aufbau des Verbrechensbegriffs, in: Festgabe Herdlitczka (n. 5), 121-142 at 138. The status theory of Hermagoras of Temnos (middle $2^{\text {nd }}$ century BC) is summarised at $124 \mathrm{ff}$.

$\left.{ }^{23}\right)$ S. Riccobono, Summum Ius Summa Iniuria, Vorwort zur italienischen Ausgabe, in: Stroux (n. 12) at 69-80; Wieacker (n. 19) at 155 n. 17 mentions other positive reactions by Maschi and Santa Cruz Tejeiro.

${ }^{24)}$ Riccobono (n. 23) at 70-74 sketches the interpolation paradigm.

${ }^{25)}$ G. Beseler, BIDR 53/54 (1948) at 349 cited by Horak, Statuslehre (n. 22) at 121 n. 3 .

${ }^{26}$ ) Wieacker (n. 19) at 156 n. 17; cf. also H.F. Jolowicz, Historical Introduction to the Study of Roman Law, Cambridge 1952, 576 for the repudiation by Levy, Beseler and Schulz; cf. also O. Tellegen-Couperus, Quintilian and Roman Law, RIDA 47 (2000) 167ff. 
man legal science ${ }^{27}$ ) labelled the last two centuries of the Roman republic, the Hellenistic period of Roman legal science. This indicates the idea and it is no surprise that Quintus Mucius Scaevola is projected as the founder of Roman legal science ${ }^{28}$ ). The position of the Roman jurist as described by Schulz deserves attention. The leading figures still belong to the most powerful families in Rome $^{29}$ ), but new faces appear, some of which succeed in a political career $^{30}$ ); others are of such low origin that they even charge for their services ${ }^{31}$ ). Advocates are viewed as a group apart, even if they have some legal knowledge ${ }^{32}$ ). Schulz uses Cicero as an example and states that he may have acquired some elementary legal knowledge ${ }^{33}$ ), but showed an absolute lack of understanding of higher legal science ${ }^{34}$ ). This distinction is crucial for Schulz's argument in terms of which the leading jurists applied the dialectic method to the law and thus built a legal science based on system ${ }^{35}$ ); these jurists remained impartial and were only interested in the truth ${ }^{36}$ ), while the advocates used all means to win their case $^{37}$ ). Schulz praises the Roman jurists for banning the weed of rhetoric from their ranks ${ }^{38}$ ), echoing the Senatus Consultum from $161 \mathrm{BC}$ expelling Greek rhetors and philosophers from

${ }^{27}$ ) F. Schulz, History of Roman legal science, Oxford 1946; idem, Geschichte der römischen Rechtswissenschaft, Weimar 1961.

${ }^{28)}$ At 97, 98, 111-113. For a deconstruction of this myth see K. Tuori, Ancient Roman lawyers and modern legal ideals, Studies on the impacts of contemporary concerns in the interpretation of ancient Roman legal history, Frankfurt 2007, ch. 2: The birth of legal science, 21-69.

${ }^{29}$ ) At 70f. "Honoratioren-Jurisprudenz"; cf. also $47 \mathrm{ff}$.

${ }^{30}$ ) At $48 \mathrm{f}$.

$\left.{ }^{31}\right)$ At 50 . At 58 he mentions that this group gave routine responsa, while the great jurists only advised their friends, important people or in difficult cases.

${ }^{32}$ ) At $50 \mathrm{ff}$.

33) Cicero studied law under Quintus Mucius Scaevola Augur.

$\left.{ }^{34}\right)$ At 52: "eine völlige Fremdheit und Verständnislosigkeit gegenüber der höheren Rechtswissenschaft".

${ }^{35}$ ) Schulz, Geschichte (n. 27) 45: "Die römische Rechtswissenschaft war einerseits soweit entwickelt, dass die griechischen Einflüsse sie nicht überwältigen konnten: andrerseits war sie noch jung und weit davon entfernt zu erstarren"; cf. 73-84 "Die dialektische Rechtswissenschaft"; also 100-102.

$\left.{ }^{36}\right)$ At 66: "Sie sind überparteiliche Wahrer und Mehrer des Rechts .... Dass es ihm nicht um Worte, sondern allein um die Wahrheit ging".

${ }^{37)}$ At $65 f$. and 82.

${ }^{38}$ ) At 66: "Es war ein Glück für die römische Rechtswissenschaft, dass die iurisconsulti fest blieben und die Wucherpflanze der Rhetorik, die so viel Schönes und Wertvolles erwürgte, in ihren Reihen nicht hochwachsen ließen." 
Rome $^{39}$ ). His Roman jurists were also opposed to Greek pedagogics ${ }^{40}$ ), did not teach, did not appear in court, were not interested in natural law, legal history, methodology, comparative law, philosophical speculations about justice nor a sociological approach ${ }^{41}$ ). In consequence, their responsa were both authoritarian and authoritative ${ }^{42}$ ). Schulz grants that the advocates adopted rhetoric theory and its topoi to use in court, but held that this had no relationship with Roman law or legal science ${ }^{43}$ ) and that the Roman lawyers could learn nothing from rhetoric $\left.{ }^{44}\right)$.

As late as 1967 Wieacker ${ }^{45}$ ) criticised Stroux for not having understood the legal question of the causa Curiana ${ }^{46}$ ). Wieacker misinterpreted Stroux's conclusions ${ }^{47}$ ) and argued that this case had been decided incorrectly ${ }^{48}$ ). To support this opinion he reviewed a number of texts ${ }^{49}$ ) and in doing so proved Stroux's major assertment to be correct, namely that Greek rhetoric provided a theory and technology for legal argumentation; that the topics provide arguments for both sides and that the Roman jurists utilised these in accordance with the circumstances and requirements of their cases.

Meanwhile, Theodor Viehweg had provided new impetus to the topoi theo$\mathrm{ry}^{50}$ ). He distinguished between topical, problem-orientated argumentation as opposed to axiomatic, systematic-deductive legal reasoning. This proposition

${ }^{39}$ ) Gell. 15,11,1; Horak, Statuslehre (n. 22) at 121 n. 4.

$\left.{ }^{40}\right)$ At 68 .

${ }^{41)}$ At 69, 84ff.

42) At $72 f$.

$\left.{ }^{43}\right)$ At 86: "Mit der griechischen Rhetorik aber haben sie (die Gerichtsredner) auch gewisse civile, ius gentium und ius civile, ius scriptum und ius non scriptum, lex und mos als species des ius, ius und aequitas. Das alles ist griechischer Import, von dem die römischen Gerichtsredner zwar praktischen Gebrauch machen, der aber mit römischem Recht und römischer Rechtswissenschaft nichts zu tun hat."

${ }^{44)}$ At 93: "Aus alledem ergibt sich: Die römischen iurisconsulti konnten hier von der Rhetorik schlechthin gar nichts lernen."

${ }^{45}$ ) Wieacker (n. 19).

46) At $156 \mathrm{f}$.

${ }^{47}$ ) At 155: From this alleged victory of higher justice over old-fashioned clinging to words Stroux drew the far-reaching conclusion that jurists were able to find true justice merely through rhetorical education.

${ }^{48}$ ) 156-161. He rejects the implication that Coponius would have wanted Curius to inherit if no son was born. His version of Scaevola's argumentation is largely based on probabilities.

$\left.{ }^{49}\right)$ D. $28,6,4$ pr.; D. $26,2,33$; D. 32,100 ; D. $28,5,70$; D. 30,63 ; D. $50,16,122$; D. 30,52. At 161-164.

${ }^{50}$ ) Viehweg (n. 6) passim. 
was inspired by Vico ${ }^{51}$ ), and Viehweg placed the origin and development in Aristotle $^{52}$ ), Cicero $^{53}$ ) and Roman law ${ }^{54}$ ). This allowed modern legal theorists to relegate Viehweg's work to legal history, and legal historians to consider it legal theory55).

After initial positive reception by Romanists ${ }^{56}$ ), reservations were expressed. Kaser $^{57}$ ) divided (Western) jurisdictions into the system-based European codifications and the Anglo-American case law $\left.{ }^{58}\right)$. He sketched Viehweg's thesis that different jurisdictions have other methodologies and agreed that a topical, problem-orientated argumentation is prima facie the methodology for case law. However, Kaser's analysis of the Roman sources led him to conclude that the Roman jurists found and developed their law not by way of rational argument, but that their intuition was the way to the correct legal answer ${ }^{59}$ ). As arguments Kaser presented the sensus iu-

${ }^{51)}$ G.B. Vico, De nostri temporis studiorum ratione, Napoli 1708. Viehweg (n. 6) $4 \mathrm{f}$. views the leading idea of this work a distinction between two scientific methods, which he typifies as the old rhetoric or topical and the new critical methods, the first transferred by Cicero, the second named after Descartes (not mentioned by Vico, who referred to Arnauld instead). Vico expressed a preference for the old method.

${ }^{52}$ ) Viehweg (n. 6) at 6-10 places topoi within the context of Aristotle's work, namely in dialectics, as a method to reach conclusions for any problem on the basis of propositions, which appear true to most people or to the wise or to the majority or the most respected of the latter group.

$\left.{ }^{53}\right)$ At 10-14 he mentions the circumstances of Cicero's Topica as well as the fact that this work, in spite of the lower standard and absence of philosophical content, has had more influence than Aristotle's work of the same title.

${ }^{54)}$ At 26-39.

$\left.{ }^{55}\right)$ M. Kas er, Zur Methode der römischen Rechtsfindung, Göttingen 1962, 49-78 at 50: "Einen wertvollen Beitrag zur allgemeinen juristischen Methodologie liefert neuerdings die Schrift von Theodor Viehweg."

${ }^{56}$ ) Horak, Rationes (n. 6) 9 n. 1 refers to H. Coing, Archiv für Rechts- und Sozialphilosophie [ARSP] 41 (1954/55) 436ff.; H. Coing, Die juristischen Auslegungsmethoden und die Lehren der allgemeinen Hermeneutik (1959); F. Wie acker, Textstufen klassischer Juristen, 1960, 286ff.; i dem, Privatrechtsgeschichte der Neuzeit, 1967, 596f.; M. Kaser, Römische Rechtsgeschichte, 1967, 172f. Cf. however, Waldstein (n. 5) 248: citation of Wieacker.

${ }^{57}$ ) Kaser (n. 55) 50f.

${ }^{58)}$ For renewed interest in the divide Ries enhuber (n. 6) 122-125.

${ }^{59}$ ) At 54: "Nach den Eindrücken, die die juristische Überlieferung zuverlässig vermittelt, steht vielmehr im Vordergrund die Intuition, also die Gewinnung der richtige Entscheidung durch ein unmittelbares Erfassen, das des rationalen Argumentierens nicht bedarf." At 55f. Kaser admits the modern scepticism regarding intuition as a scientific method. 
ridicus, which evolved into a genius for juristic ethics of the Roman peo$\mathrm{pl}^{60}$ ), Roman realism, traditionalism, the fact that the republican Roman jurists belonged to a small ruling class, and finally experience $\left.{ }^{61}\right)$. He acknowledged that during the second century $\mathrm{BC}$ demands for rational motivation of the responsa may have played a role ${ }^{62}$ ), but held that this was temporary as the practice-orientated Roman lawyers felt no need for theo$\left.\mathrm{ry}^{63}\right)$. Kaser also distinguished between lawyers and rhetors on the basis of their objectives: the rhetor strived for success in court, using topoi from all walks of life ${ }^{64}$ ), but the Roman jurists moved on a higher ethical plane and aimed for the realisation of justice ${ }^{65}$ ). Allowing for some Greek influence during the second century $\mathrm{BC}$ Kaser believed that Schulz exaggerated ${ }^{66}$ ) and that the interpolationists had shown that many regulae, definitiones, distinctiones and differentiae in the Digest were of Byzantine origin $\left.{ }^{67}\right) . \mathrm{He}$ concluded that the Romans had developed a highly sophisticated juristic instrumentarium, superior to any topoi catalogue, as well as an internal system $^{68}$ ), but granted a difference between the Pandektists and the Roman approach $\left.^{69}\right)$.

$\left.{ }^{60}\right)$ At 56 .

${ }^{61)}$ At $56 \mathrm{f}$.

${ }^{62}$ ) At 58 .

${ }^{63)}$ At 58 and 70 .

${ }^{64)}$ At 67: Topoi aus allen Lebensbereichen.

${ }^{65}$ ) At 73: die materiale Gerechtigkeit zu verwirklichen.

${ }^{66)}$ At 68 .

${ }^{67)}$ At 72 .

${ }^{68}$ ) At 66 and $72 \mathrm{ff}$. Kaser's internal system is echoed by M.W. Hesselink, A European legal method? On European private law and scientific method, in: European Law Review 15 (2009) 20, 28ff. cited by Riesenhuber (n. 6) at 126: “A systematic approach is what Hesselink has recently described as an internal perspective as opposed to an external perspective of the law ...". At 124 Riesenhuber had stated: "As the example of Roman law illustrates, a case law approach can, at the same time, be systematic." For this pearl he relied on J.D. Harke, Juristenmethode in Rom, in: K. Riesenhuber (ed.), Europäische Methodenlehre, 2010, §2. At 30 Riesenhuber concludes: "While the common law tradition and the continental legal systems differ substantially with regard to the sources of the law, it is submitted that they do not differ as much with regard to the methods for finding the law. A case-by-case approach proceeds by analogy or distinction and is no less concerned with equality or coherence than a systematic approach on the basis of codified law. Both, common lawyers and civil lawyers have in common that they pursue internal approaches to the law."

${ }^{69}$ ) At 77. 
In Rationes decidendi ${ }^{70}$ ), an analysis of the grounds for the decisions of the Roman jurists until Labeo ${ }^{71}$ ), Horak made a learned contribution to the discourse. He included a preliminary on science ${ }^{72}$ ), but found little consensus. Nevertheless, Horak deduced certain basic requirements, such as the necessity of a system ${ }^{73}$ ) and rational justification ${ }^{74}$ ). He argued that no material differences exist between natural and human sciences and that in reality no science consists of only one system, but of a plurality of component systems. He differentiated between discovery and justification, acknowledging the role of intuition in the first ${ }^{75}$ ), but not in the latter ${ }^{76}$ ). His insistence on system, rationality, method, logical analysis and argumentation made him reject the opinions of Vico and Viehweg ${ }^{77}$ ). This same persistence made him distinguish between "Rechtswissenschaft" and "Rechtspolitik"78) and refer to the pseudo-scientific methods of legal science ${ }^{79}$ ). In spite of his dismission of Viehweg ${ }^{80}$ ), Horak

$\left.{ }^{70}\right)$ Supra $n 6$.

$\left.{ }^{71}\right)$ Marcus Antistius Labeo, deceased around 10 AD.

72) At 9-22.

73) At $10-16$.

${ }^{74)}$ At $12,16,20 \mathrm{ff}$.

${ }^{75}$ ) At 18ff. At 18 n. 24 Horak cites Einstein (Mein Weltbild, 1934, 168) as authority.

${ }^{76}$ ) At 20f.; cf. however F. Bydlinski, Bewegliches System und juristische Methodenlehre, in: F. Bydlinski et al. (eds.), Das Bewegliche System im geltenden und künftigen Recht, Wien 1986, 21 at 29: "Nur in einem zwar durchaus relevanten, aber eben unproblematischen Bereich routinemäßiger Rechtsanwendung führt bereits bloße deduktive Ableitung aus den vorfindlichen Rechtsnormen zu eindeutigen und zureichenden Ergebnissen. Es ist der Grundfehler der üblichen rechtspositivistischen Ansätze, dass sie nur diesen Bereich und darüber hinaus nur die rechtlich freie Entscheidung des zuständigen Rechtsorgans kennen und kunstvoll alle argumentative Rechtsgewinnung dazwischen wegdefinieren."

${ }^{77)}$ At $15 \mathrm{f}$.

${ }^{78}$ ) At 34f., 39, 53, 62ff.

$\left.{ }^{79}\right)$ At $27 \mathrm{ff}$. he discusses the special position of norms in law. At $30 \mathrm{ff}$. he opposes the use of analogy. However, Rie senhuber (n. 6) at 122125 believes that proceeding by analogy is inherently linked to systematic thinking. For procedure ad similia B en ke (n. 3) 30-43. Horak, Rationes (n. 6) at 36ff. addressed the role of value judgments in jurisprudence.

${ }^{80}$ ) 45-64; cf. however Horak at 64: "Die Behauptung, die Jurisprudenz arbeite tatsächlich in besondere Weise spezifisch 'topisch', ist insoweit richtig, als in der Jurisprudenz tatsächlich oft Rechtspolitik (in der Form von richterlichen etc. Entscheidungen) als Rechtserkenntnis ausgegeben wird. Dann werden Wertungen (auch bei der Anwendung von sog. Analogie- oder Induktionsschlüssen) durch 'topoi', d. h. durch Gesichtspunkte sehr heterogener Art, scheinbar rational begründet” [italics by F.H.]. 
recognised the influence of Cicero's Topica in legal argumentation ${ }^{81}$ ). Waldstein also addressed Viehweg's topics and Kaser's intuition and concluded that the first had misunderstood Aristotle ${ }^{82}$ ) and omitted Miquels' work on the influence of Stoic logic in Roman law ${ }^{83}$ ); Waldstein also held Viehweg to be ignorant of Roman legal history ${ }^{84}$ ). For Kaser's intuition he found, however, support in the works of Aristotle, Plato and Stoa $\left.{ }^{85}\right)$.

3. Analysis and critique:

\subsection{Changing and changeable meanings:}

Derek van der Merwe ${ }^{86}$ ) has drawn attention to the variety of meanings of dialectics ${ }^{87}$ ) and the ambiguous place of topoi within this theory of science ${ }^{88}$ ). The esteem of dialectics runs from Aristotle ${ }^{89}$ ) to Cicero ${ }^{90}$ ), and via Marx

$\left.{ }^{81}\right)$ For example, p. 48: "Schließlich gibt es in dem Büchlein [= Cicero's Topica] so manches an Argumentationslehre, was spätere Jurisprudenz ausgiebig verwendet hat und heute noch verwendet"; at 57: "Niemand wird bestreiten, daß in der Jurisprudenz heute wie eh und je mit diesen 'Gesichtspunkten' argumentiert wird. Es sei also rundweg zugegeben, daß die Jurisprudenz tatsächlich topisch arbeitet”. See also Horak, Statuslehre (n. 22) 121-142. Horak compared the status theory with modern criminal law doctrine.

${ }^{82}$ ) Waldstein (n. 5) at $242 \mathrm{ff}$.

${ }^{83)}$ At 245247.

84) At $247 \mathrm{f}$.

$\left.{ }^{85}\right)$ At $248-263$.

${ }^{86)}$ Van der Merwe (n. 8) 129-152.

${ }^{87}$ ) At 133f. he mentions the different meanings in Plato's work and discusses the wider denotation in Aristotle's Organon. At 134 he points out the broader sense in the works of Stoa and the eventual generality and hints at the Roman version developed by Cicero. At 141 the Byzantine and at 142 Boethius' adaptations are summarised and at 144 the medieval concept is set out. He gives Kneale, The Development of Logic (1962), Schulz 1953 (n. 27), Prantl, Geschichte der Logik im Abendlande, vol. I (1855), Herberger, Dogmatik, Zur Geschichte von Begriff und Methode in Medizin und Jurisprudenz, 1981 and Viehweg, Topik und Jurisprudenz, 1953 as his main sources.

${ }^{88}$ ) At 133 van der Merwe translates Aristotle's topoi as points of view and then interprets topos as a strategy for presentation of an argument, which in most cases is build upon a principle. Cicero's locus, the seat of an argument, becomes an argument at 139 and in Boethius' version of the theory of topoi; topos is described as a maxima propositio, an obvious and fundamental truth, see 142. At 146ff. the medieval view on topoi as arguments and the synthesis of Everardus' Topica seu de locis legalibus is followed by the humanist scientific systematising and the reversal of importance of loci by the development of principia iuris of axiomata.

${ }^{89}$ ) Van der Merwe (n. 8) 133 refers to dialectics as the art of arts and the science of sciences.

$\left.{ }^{90}\right)$ Top. 2. See also 10 where Cicero describes the use of similarities and compari- 
to Schul ${ }^{91}$ ) and Viehweg, but their interpretations differ. In the same manner Horak remarked on the different ideas about science ${ }^{92}$ ), while Waldstein mentioned the intellectual and methodical variety within Greek philosophy ${ }^{93}$ ).

\subsection{Greek influence:}

The influence of Greek culture on Roman society, in particular during the two centuries after the second Punic war, is commonplace and Roman law was not immune $\left.{ }^{94}\right)$. However, the debate which school of philosophy, at a given period and in which Roman circles was influential in Rome, is far from concluded. Winkel has warned against hasty conclusions and stated that a distinction should be made between philosophical and rhetorical influences ${ }^{95}$ ). Kaser believed that this influence should not be over-estimated ${ }^{96}$ ).

It is submitted that there appears to be a paradox when authors, who make the practicality and practice-orientation of the Roman jurists an a priori, also pretend that Greek dialectics - be it in Aristotelian or Stoic form ${ }^{97}$ ) - seriously influenced the development of Roman law. It should be noted that near the end of his life, the well-educated, intelligent and hard-working Cicero appears to have had only vague knowledge of Aristotle's Topo $i^{98}$ ) and that his philosophy was rather mix and match ${ }^{99}$ ). However, to denigrate and selectively ignore Cicero $^{100}$ ), and to profess the belief that the Roman jurists, these so-called men

son to reach a conclusion by way of induction, the favorite method of Socrates: Si tutor idem praestare debet, si socius, si cui mandaris, si qui fiduciam acceperit, debet etiam procurator. Haec ex pluribus perveniens quo vult appellatur inductio, quae Graece

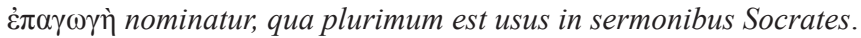

$\left.{ }^{91}\right)$ At 68 he describes dialectic as the fire of Prometheus for Roman jurisprudence.

${ }^{92}$ ) For more recent ideas cf. Benke (n. 3) passim; Ries enhuber (n. 6) passim.

${ }^{93}$ ) Waldstein (n. 5) at 239.

${ }^{94}$ ) Schulz (n. 27) at 38f. talks about the Hellenistic period of Roman jurisprudence; also at 100.

$\left.{ }^{95}\right)$ L.C. Winkel, Error iuris nocet: Rechtsirrtum als Problem der Rechtsordnung, Zutphen 1985, at $65 \mathrm{ff}$. Cf. Stroux (n. 12) 5f. who warned that the influence of Stoa on the jurists should not be exaggerated and that the Perepatetici and Academic influenced methodology to a greater extent.. He refers to Rhet. Her. 2,16.

${ }^{96}$ ) At 68.

${ }^{97}$ ) Schulz (n. 27) at 100.

${ }^{98}$ ) It is generally accepted that Cicero's memory deceived him about Aristotle's Topoi, or that he possessed a work, which differed from what is currently accepted as this work. For the transmission of Aristotle's work see Winkel (n. 95) at 68-76.

${ }^{99}$ ) D.H. Van Zyl, Cicero's legal philosophy, Roodepoort 1986; idem, Justice and equity in Greek and Roman legal thought, Pretoria 1991; id em, Justice and equity in Cicero: a critical evaluation in contextual perspective, Pretoria 1991.

${ }^{100}$ ) For example Horak, Rationes (n. 6) 47f.; van der Merwe (n. 8) 134; Viehwe g (n. 6) 26; Schulz (n. 27) at 53, 61, 82, 87, 91 n. 2, 111 and 113. Since Mommsen 
of practice, had the intellectual means, time or inclination, to master and apply dialectics to their profession ${ }^{101}$ ) is an inconsistency. That practical lawyers would make use of topoi, for which they had immediate, practical application seems more probable.

\subsection{System:}

It is trite that the humanists were the first to systematise (Roman) law, albeit for didactic purposes ${ }^{102}$ ). The seventeenth century scientific revolution resulted in a general paradigm shift as observed and deplored by Vico. Natural lawyers drew inspiration from Descartes, Spinoza and similar thinkers and strived to mathematise and rationalise law. This Euclidean Idealtypus of a closed system with logical deduction ${ }^{103}$ ) was expected to be realised in codification. During the nineteenth century the Pandectists carried the torch. Tuori ${ }^{104}$ ) has traced how the scientific beginnings of Roman law were invented to trump the claims of the Germanists ${ }^{105}$ ). The resulting narrative described the history of Roman law as the development of legal science and the concomitant system. The interpolationists were the logical consequence, and it should be kept in mind that the system builders and deductive reasoners are still active $\left.{ }^{106}\right)$. However, Quintilian already explained that if it were always possible to solve disputed questions from generally admitted premises, the advocate would be of little use ${ }^{107}$ ).

the reverence of Tully has ebbed, although the nadir of his reputation when he was represented as a mere translator and simplifier of Greek culture without a grain of originality has been passed. Cf. Marcia Colish, The Stoic tradition from Antiquity to the early Middle Ages, Leiden 1985, 1, 65-152; P. J. Thomas, Bona fides, Roman values and legal science, Fundamina 10 (2004) 188 at 191.

101) Schulz (n. 27) at 94; van der Merwe (n. 8) 135f. Kaser (n. 55) at 68ff. is more realistic in his evaluation.

$\left.{ }^{102}\right)$ P. J. Thomas, Die renaissance in die reg, in: De Jure 23 (1990) 57-66.

103) Admiration for the mathematical precision of Roman legal science was expressed by F.C. von Savigny, Vom Beruf unserer Zeit für Gesetzgebung und Rechtswissenschaft, Heidelberg 1814, 28f., and Leibniz (cf. F. Sturm, Das römische Recht in der Sicht von Gottfried Wilhelm Leibniz, Tübingen 1968) and R. von Jhering, Geist des römischen Rechts auf den verschiedenen Stufen seiner Entwicklung, Leipzig 1906, III/1 9f., 318f., 321f.; cf. Horak, Rationes (n. 6) 65ff.

${ }^{104)}$ Tuori (n. 28) at 23-47.

105) G. Hugo, Lehrbuch der Geschichte des römischen Rechtes, Berlin 1806, at 341f., 352ff.; G.F. Puchta, Cursus der Institutionen, Leipzig 1875, I 174f., $244 \mathrm{ff}$. Cf. the title of F.C. von Savigny, System des heutigen römischen Rechts, Berlin 1840-1849.

${ }^{106)}$ Riesenhuber (n. 6) $118 \mathrm{ff}$.

${ }^{107}$ ) Quint. inst. 5,14,14f. In 5,14,18ff. Cicero's Pro Milone is used to exemplify. 
Kaser ${ }^{108}$ ) depicted Viehweg's division of legal systems and legal thinking as absolute, an either-or, and remarked that even topical argumentation cannot do without deduction and that even case-built jurisdictions have an internal system ${ }^{109}$ ).

Van der Merwe ${ }^{110}$ ) pragmatically summarised the influence of dialectics in Roman law in that the tentative steps of Scaevola ${ }^{111}$ ), taken up by Sabinus culminated in the institutional system of Gaius, a tool in legal education, but hardly a coherent legal system.

\subsection{The correct legal solution:}

Duncan Kennedy tells how first-year American law students are introduced to a so-called hot and cold case. The first case involves a sympathetic plaintiff and an unsympathetic defendant, for example an Appalachian farm family and a coal company. The latter had rented the farmer's land for strip mining with the promise to restore it to its original condition once the coal had been mined. The company reneged on this promise and the court awarded a few hundred dollars instead of ordering the restoration work. The student is taught that her initial reaction is naïve, non-legal, irrelevant and wrong; that there are good reasons for the decision, when you take a legal and logical large $\left.v^{1} w^{12}\right)$. The legal argumentation is never explicitly explained, but leads to the correct legal solution.

The authority of Kaser is such that his essay on the method of the Roman jurists has hardly ever been questioned. However, both Horak and Waldstein have suggested that intuition may have helped Roman lawyers to find a solution and arguments, but cannot replace legal argumentation. Moreover, the idea that there is one correct legal solution does not convince today. In Aufstieg und Niedergang der römischen Welt ${ }^{113}$ ) Waldstein ${ }^{114}$ ) has provided scientific objections, but one simple criticism is that approval of Kaser's proposition implies intuitive acceptance of the Roman legal solution by the reader. This is a variation on the chicken and egg conundrum, since until recently

${ }^{108)}$ Kaser (n. 55).

$\left.{ }^{109}\right)$ At $50-53$.

$\left.{ }^{110}\right)$ At $135-139$.

111) Quintus Mucius Scaevola (ob. 82 BC). Cf. D. 1,2,2,41; Stein (n. 4) at 1544.

${ }^{112}$ ) At 41: "if you can't muster those reasons, maybe you aren't cut out to be a lawyer".

113) H. Temporini/W. Haase (eds.), Aufstieg und Niedergand der römischen Welt, Geschichte und Kultur Roms im Spiegel der neueren Forschung, Berlin 1976, vol. II 15 Principat.

${ }^{114}$ ) W. Waldstein, Entscheidungsgrundlagen der klassischen römischen Juristen, in: Temporini/Haase (n. 113) 3-100 at 4-10. 
all jurists started their studies with a healthy dose of Roman law to lay the foundation of their legal knowledge and instil the art of legal reasoning. In consequence, the proposition that the Roman legal solutions are correct would in the recent past hardly be met with opposition ${ }^{15}$ ).

However, Max Weber and the popularisation of the ideas of the Frankfurter School after 1968 have placed different values and interests in society within the scientific debate ${ }^{116}$ ). This has placed the correct legal solution in a subjective cultural context. The subtext of Duncan Kennedy's essay is that 'thinking like a lawyer' means that virtually any solution can be argued in an acceptable manner ${ }^{117}$ ), refuting the distinction between jurists and barristers ${ }^{118}$ ).

Bydlinski has also argued that in virtually every serious legal problem both sides can raise good legal arguments ${ }^{119}$ ), and that the outcome of a legal problem is co-determined by a variety of factors. It is nowhere denied that a large part of legal disputes is solved by simple deduction from an uncontested rule ${ }^{120}$ ), but this paper attends to those cases in which for both sides good

115) Cf. Horak, Rationes (n. 6) 3.

${ }^{116}$ ) The Frankfurter School and the resulting Critical Theory debunked the so-called objectivity and rationality of the human sciences. P. J. Thom as, Wetenskaps filosofie en die regswetenskap, in: Tydskrif vir Hedendaagse Romeins-Hollandse Reg [THRHR] 58 (1995) 39-42. Science can become an ideology to justify the facts and that the rationality of positivism is teleological. M. Horkheimer/Th. W. Adorno, Dialectic of Enlightenment, New York 1992, 3-43. Habermas has argued that the positivistic distinction between facts and values has been replaced by the recognition that facts and values are interdependent and that the so-called objective science never reveals the interests guiding it and that so-called objective scientific knowledge is constructs based on a special interest, J. Habermas, Rationalism divided in two, in: A. Gidden s (ed.), Positivism and Sociology, London 1974, $213 \mathrm{ff}$. These ideas are reflected in both the essays of Kennedy (n. 1) and Benke (n. 3).

${ }^{117}$ ) At 43ff. For and in-depth analysis and elaboration on the same D. Kennedy, A semiotics of legal argument, in: Syracuse Law Review 42 (1991) 75; i dem, Collected courses of the academy of European law (1994) vol. III, 309-365.

${ }^{118}$ ) The barristers using all including questionable means and arguments from all walks of life to win their case, while the jurists are only interested in the realisation of material justice; Kaser (n. 55) at 67, 73.

${ }^{119}$ ) Bydlinski (n. 76) at 28f. where he also holds: "Tatsächlich geht es in der Jurisprudenz, wie sie praktisch betrieben wird und betrieben werden muss, weithin um die Erarbeitung und Abwägung von Rechtsgewinnungsargumenten, die ergeben, dass die eine der möglichen Problemlösungen rechtlich vorzuziehen ist, weil sie relative besser dem Recht (den vorfindlichen Rechtsnormen und dem vorfindlichen sonstigen Rechtsgewinnungsmaterial) entspricht."

${ }^{120}$ ) Bydlinski (n. 76) at 29: "Nur in einem zwar durchaus relevanten, aber eben unproblematischen Bereich routinemäßiger Rechtsanwendung führt bereits bloße de- 
arguments can be raised and investigates the hypothesis that the oratorical training of the educated Roman during the late republic determined legal argumentation, in other words created the mould for 'thinking like a lawyer'.

Kaser's argument ${ }^{121}$ ) that many of the regulae, definitiones, disctinctiones and differentiae in the Digest have been shown to have been interpolations by Byzantine post-classical law schools belongs to an earlier paradigm, while his argument that there were many more controversiae than we are aware of, since both Gaius and Justinian deleted much ${ }^{122}$ ), is grain on the mill of Viehweg.

\subsection{Idealised version of Roman jurists:}

Wieacker's description of Scaevola is classic: an old aristocratic jurist, who as a rule stood as an impartial adviser above the parties. His cousin, the augur looked down with amused contempt on the juristic ignorance of the average court speaker ${ }^{123}$ ). Wieacker considered the cryptic rationes decidendi an expression of tact mellowed through long experience ${ }^{124}$ ). Kaser's admiration of the Roman jurist shows throughout his work and he describes the lawyers who by the way were foremost politicians - as the standard-bearers of high ethics ${ }^{125}$ ), not interested in winning cases in court, but striving for the realisation of justice $\left.{ }^{126}\right)$. This vision results in minimising the influence of topics, rhetoric, dialectics or logic in the development of Roman law. The arguments that the Romans had exceptional talent for justice ${ }^{127}$ ) and that the Roman jurists originally belonged to a small ruling class, which was a safeguard against

duktive Ableitung aus den vorfindlichen Rechtsnormen zu eindeutigen und zureichenden Ergebnissen. Es ist der Grundfehler der üblichen rechtspositivistischen Ansätze, daß sie nur diesen Bereich und darüber hinaus nur die rechtlich freie Entscheidung des zuständigen Rechtsorgans kennen und kunstvoll alle argumentative Rechtsgewinnung dazwischen wegdefinieren."

$\left.{ }^{121}\right)$ At 71 .

122) At 75 .

${ }^{123}$ ) Wieacker (n. 19) at 157f.

${ }^{124}$ ) At 164: "insofar as the jurists give any reasons for their decisions at all, all we have is mostly a short apercu; a reflection upon the general theory of the exegesis we find only in the writings of Celsus unique. This was neither old-fashionedness nor superficial pragmatism on the part of those great jurists, but tact mellowed through long experience." Wieacker believed the topics too clumsy to offer criteria needed for a balanced evaluation of the interests involved and held that at most they may give an approximate idea of the possible points of view.

125) At 67.

126) At 73 .

${ }^{127}$ ) Contra Horak, Rationes (n. 6) 1 who quotes from Mommsen's inaugural lecture in Zürich (1852) to the same effect. 
subjectivity ${ }^{128}$ ), are also questionable. Horak remarked that the idealised image of the Roman jurists should be adapted to a more realistic world-view and queried whether the lawyers' ethics were indeed so much better than those of the advocates $\left.{ }^{129}\right)$. Winkel has referred to Kop in the same vein $\left.{ }^{130}\right)$.

\subsection{Isolation of Roman law and resulting pole position:}

It has been argued that Roman law was not open to these foreign influences on account of the closed circle of jurists and the self-sufficient nature of Roman law ${ }^{131}$ ). This conviction is essential to support other beliefs, namely the idea that Roman legal science is the origin of modern legal science ${ }^{132}$ ); that Roman law was ratio scripta, and the autonomy of law ${ }^{133}$ ). The latter is the fiction that law, from Roman law onwards at least, is separate from society, an idyllic, rational island irrespective of the surrounding world ${ }^{134}$ ). Thus, injustice has no

128) The fact of the small closed group, brought to the fore by Schulz (n. 27) at $27 \mathrm{ff}$. and 70ff. ("Honoratiorenjurisprudenz") has as many cons as it has pros. It may be realistic to give attention to the authoritarian attitude of this group and the corruption concomitant with a closed oligarchy, for which argument ample support is to be found in Roman literary sources.

$\left.{ }^{129}\right)$ At 122. Winkel (n. 95) at 68: "Nachdem [i.e. Wieacker 1950 and 1969] inzwischen einige Versuche unternommen wurden, nachzuweisen, dass diese Idealisierung der Juristen als eines besonderen Berufstandes im Grunde ein unhistorisches Vorurteil war." A possible origin of this idolising may be found in the work of von Savigny. Cf. G. Schmid, Review of Traité de la Possession (French translation of Das Recht des Besitzes), in: Louisiana Law Journal 1 (1841) 46 at 59: "The author [i.e. von Savigny], intimately acquainted with ancient Rome ... seems to entertain for everything appertaining to this ancient Mistress of the world a veneration which forbids him even to examine the justice and expediency of the principles of her legislation and still less to doubt the fairness and propriety". Gustav Schmid was a leading Louisiana jurist who published The Civil law of Spain and Mexico (1851) and was the founder of the Louisiana Law Journal.

${ }^{130}$ ) At 68 (n. 12) he refers to P.C. Kop, Beschouwingen over het zgn. 'vulgaire' Romeinse Recht, Leiden 1981, passim.

${ }^{131}$ ) Schulz (n. 27) at 84ff. describes the boundaries of Roman jurisprudence, which meant that philosophy, methodology, legal history and comparative law were kept outside legal science; Horak, Rationes (n. 6) 48: “Aber der römische Jurist scheint zu sehr in den Schranken seines Fachs befangen gewesen zu sein, als daß er so Ungewohntes hätte in seine Wissenschaft integrieren können"; Ka ser (n. 55) at 67 even held against rhetoric that topoi from all walks of life were used.

132) Tu ori (n. 28) at 21-69 for the competing genealogies of Western legal science. References to the opinions of the authors cited in this paper, but also to Senn, La Pira, Schulz, Stein, Watson, Frier, Pugliese, Giaro, Bederman, Behrends et al are found in this excellent analysis.

133) Tuori (n. 28) at 71-134.

${ }^{134}$ ) Tuori (n. 28) at $71 \mathrm{f}$. 
relation to or influence on or from the legal system and/or legal science. It is against this background that the hypotheses of Stroux and Viehweg must be considered, since both authors questioned the scientific foundations of Roman law and thus Western legal tradition. The proposed substitutes, the status theory of Hermagoras and Cicero's version of topics, did not meet modern scientific standards and placed jurisprudence in the middle of Roman life and society.

4. Zone of possible agreement:

Most deconstruction of Stroux and Viehweg omits to offer an alternative ${ }^{135}$ ). This paper aims to find, albeit ex post facto, a zone of possible agreement.

4.1. Greek influence; oratorical studies:

First, it is without contention that during the second century B.C. Greek culture came to Rome and influenced most aspects of Roman life $\left.{ }^{136}\right)$. There is also general acceptance that during the later republic oratorical training was the only higher education available and useful to the Roman upper classes ${ }^{137}$ ). No such consensus exists regarding the influence of Greek philosophy on Roman jurisprudence ${ }^{138}$ ), let alone which school of Greek philosophy may have been influential. Thus, van der Merwe's cautious conclusion that the influence of dialectics on Roman law remained limited to the institutional system of Gaius, stands ${ }^{139}$ ).

\subsection{Case law:}

Roman law was case law throughout Roman history. Schulz wrote that the aspiring lawyer was immediately confronted with the eternal question: what to do in the present case $\left.{ }^{140}\right)$ ? Kaser stated that in actual cases the decision is often not reached by deduction from an absolute truth, but reached by a process of induction and he agreed that lawyers in court argue by way of topics ${ }^{141}$ ).

4.3 Thinking like a lawyer, legal argumentation, legal interpretation, legal methodology:

Wieacker believed that during the republic the ius honorarium supplemented the formalism of the old ius civile through a progressive legal ethic found

135) Wieacker (n. 19) at 164 explains the absence of motivation on account of tact mellowed through experience and refers to a balanced evaluation of the interests involved.

${ }^{136}$ ) Kaser (n. 55) at 71; Schulz (n. 27) at 45, 75ff.; Waldstein (n. 5) at 239; Wieacker (n. 19) at 164.

${ }^{137}$ ) Schulz (n. 27) at 64, 74ff; Waldstein (n. 5) at 259.

${ }^{138}$ ) Winkel (n. 95) at 64ff.; Wieacker (n. 19) at 152.

$\left.{ }^{139}\right)$ At 135-139.

$\left.{ }^{140}\right)$ At 69.

${ }^{141)}$ At 5973 . 
in the ideas of bonum et aequum and bona fides and that an independent juristic technique developed, which made it possible to solve social conflicts according to a rational intellectual rule ${ }^{142}$ ). He admitted that juristic argumentation had seldom been investigated.

Kaser acknowledged that during the second century B.C. the jurists appeared in court alongside the rhetors, which led to demands for rational motivation ${ }^{143}$ ); this rational method was topical, that is searching for arguments to solve a case. Where the rational method was present, namely in topical argumentation, the search for topics and arguments was guided by intuition. Thus Kaser agreed that jurisprudence and rhetoric shared a methodology ${ }^{144}$ ), and many of the arguments used by the Roman lawyers described by him ${ }^{145}$ ) and the associative thinking he referred ${ }^{146}$ ), are the topoi of Cicero and Viehweg. Horak's findings on the rationes decidendi raise the question regarding the exact difference between Cicero's and Viehweg's topica and Horak's types ${ }^{147}$ ).

5. Conclusion:

Stroux was criticised for not being a lawyer ${ }^{148}$ ), but it can be argued that this so-called weakness in effect was a strong point. He was not integrated in and indoctrinated by $20^{\text {th }}$ century legal science and thus stood outside the ruling dogma. Stroux's thesis that Greek rhetoric led to the adoption of a system for free interpretation of statutes and documents was contrary to the beliefs of the ruling paradigm ${ }^{149}$ ). The retort that he overestimated the importance of the causa Curiana and that this case was wrongly decided ${ }^{150}$ ) does not invalidate his argument. Viehweg took as point of departure that legal argumentation in case law jurisdictions differs from that in codified legal systems. His theory distinguished between problem-orientated argumentation making use of topics as opposed to systematic-deductive legal reasoning using axioms; whether he misunderstood Aristotle is also immaterial ${ }^{151}$ ).

142) At 151 .

143) At 58 .

${ }^{144)}$ At 67.

${ }^{145)}$ At 59 he mentions analogy, e contrario, regulae.

${ }^{146}$ ) At 69f.; also Benke (n. 3) 30ff.

147) At 78ff.

${ }^{148}$ ) Wieacker (n. 19) at 157.

${ }^{149}$ ) Cf. Jolowicz (n. 26) at 576f.; Tellegen-Couperus, Quintilian (n. 26) at $167 \mathrm{ff}$.

${ }^{150}$ ) Wieacker (n. 19) at 161.

${ }^{151}$ ) Horak, Rationes (n. 6) 45-65. The latter acknowledges the influence of Cicero's Topica in Roman law, but denigrates this as "Rechtspolitik", which falls outside his dogmatic and outdated concept of "Rechtswissenschaft". For example at 48: 
It is submitted that on the basis of the zone of possible agreement, Kaser's methodology could be updated and adapted. If the role of intuition is placed in the context of discovery ${ }^{152}$ ), as a guide in the search for arguments, topoi, and his image of the Roman lawyer is brought down-to-earth, his analysis of the methodology of the Roman lawyers would show that thinking like a Roman lawyer consists in problem orientated, topical legal argumentation. The seminal importance of Kaser's essay is found in his emphasis on the absence of absolutes, so that in all legal orders deduction and induction operate side by side; that both are rational methods and that the topoi in Roman law were not limited to the regulae of D. 50,17. However, Kaser's objection that in rhetoric topoi from all aspects of life were used, should be ignored. Exactly this point opened the possibility to take political and socio-economic arguments into consideration, which resulted in the many controversiae.

I would like to conclude by mentioning the observation of Tomasz Giaro ${ }^{153}$ ) namely that the Roman jurists did not care whether their work was scientific or not, and that the obsession to prove the scientific nature of Roman jurisprudence is anachronistic neo-positivism.

\footnotetext{
"Schließlich gibt es in dem Büchlein [= Cicero's Topica] so manches an Argumentationslehre, was spätere Jurisprudenz ausgiebig verwendet hat und heute noch verwendet. Aber der römische Jurist scheint zu sehr in den Schranken seines Fachs befangen gewesen zu sein, als daß er so Ungewohntes hätte in seine Wissenschaft integrieren können."

${ }^{152}$ ) Horak, Rationes (n. 6) 43: “Auch in der Jurisprudenz hat daher Intuition ihren Platz bei Entdeckung, nicht aber bei Begründung von Entscheidungen.”

$\left.{ }^{153}\right)$ T. Giaro, Die Illusion der Wissenschaftlichkeit, Index 22 (1994) 118-128.
} 